\title{
Agritourist Motivations: The Case of Turkey
}

\author{
Savaş Artuğer ${ }^{1} \&$ Hakan Kendir ${ }^{1}$ \\ ${ }^{1}$ Zile Dincerler School of Tourism and Hotel Management, Gaziosmanpaşa University, Turkey \\ Correspondence: Savaş Artuğer, Zile Dincerler School of Tourism and Hotel Management, Gaziosmanpaşa \\ University, Alaca Yolu 3. Km, Zile, Tokat, Turkey. E-mail: artugersavas@yahoo.com
}

Received: August 23, 2013

Accepted: September 22, 2013

Online Published: October 15, 2013

doi:10.5539/ijbm.v8n21p63

URL: http://dx.doi.org/10.5539/ijbm.v8n21p63

\begin{abstract}
The aim of this study is to determine what motivated agritourists of Turkish origin to participate in agritourism in Turkey. In line with this target a survey has been carried out with 196 Turkish agritourists who participated in agritourism in Turkey. Agritourist motivation scale was used as a tool to collect data for the application and an online survey link was dispatched to the e-mail addresses of the agritourists to be filled between January and March of 2013. Arithmetical average, standard deviation, factor analysis and reliability analysis were used in the study. The results of the study revealed that Turkish agritourists had participated in agritourism for reasons such as to enjoy scenery, life and mental relaxation. In other words agritourists participated in agritourism in order to relax physically or mentally and be in touch with nature.
\end{abstract}

Keywords: agritourism, agritourist motivations, agritourism farms, Turkey

\section{Introduction}

During the past thirty years the increase of input costs in the agricultural sector, low sale prices of produced products, climate change, globalization, negative agricultural policies implemented by governments have channeled farm proprietors into diversifying their products. Agritourism is one of such product varieties (McGehee, Kim, \& Jennigs, 2007; Yang, 2012). For a long time agritourism has been indicated as a significant element in the socio-economic development and renaissance of rural regions. There are various reasons why agritourism has gained significance in rural regions. The principle reason is that it has an economic and social contribution to rural communities. In addition, there are other reasons such as providing additional revenue to farms, promoting and protecting environmental and cultural values as well as providing a source of employment for local communities (Yang, 2012).

Studies involving agritourism are mainly focused on farms. These studies (e.g. Nickerson, Black, \& McCool, 2001; McGehee \& Kim, 2004; McGehee et al., 2007; Barbieri, 2010) usually deal with the reasons why farm owners operate agricultural farms. The results from these studies indicate that the main reason farm owners undertake agritourism is to earn additional income and ensure job opportunities for family members (Nickerson et al., 2001; McGehee \& Kim, 2004). On the other hand, it is evident in literature that the number of studies in terms of agritourists and particularly studies researching the reasons why agritourists participate in agritourism (Jolly \& Reynolds, 2005; Che, Veeck, \& Veeck, 2006; Srikatanyoo \& Campiranon, 2010) is limited.

Within the framework of the above information the purpose of this study is to determine the motivations of Turkish agritourists to participate in agritourism. It is believed that the results achieved from this study will contribute to the few numbers of studies made in this area.

\section{Literature Review}

Numerous researchers have made various definitions in literature regarding agritourism. Here are some of them: According to Weaver and Fennell (1997, p.357) agritourism is "the corporation of a farmhouse with a tourism component". Mitchell (2006) claims that agritourism is a phenomenon in which people go and observe and experience daily farm conditions. According to Prezezborska (2003) agritourism is the merging of all tourism and recreational activities with any farm activity (Busby \& Rendle, 2000). Agritourism consists of many activities such as accommodation at the farmhouse, participating in agricultural festivals, hunting, picking self-grown products, bird-watching, horse riding, walking (Barbieri \& Mshenga, 2008; McGehee et al., 2007). 
In Turkey agritourism was incepted by Buğday Association for Supporting Ecological Living with the support of the United Nations Development Program in 2004 (www.bugday.org). The "Eco-Agro Tourism and Voluntary Knowledge and Skills Exchange on Organic Farms" organized by Buğday Association for Supporting Ecological Living (Ta-Tu-Ta) project is a bridge between farmers producing nature friendly products in the rural area and urbanites who wish to get acquainted with the culture of soil (http://www.ntvmsnbc.com). With the Ta-Tu-Ta project the Buğday Association is the sole representative of WWOOF (Worldwide Opportunities on Organic Farms) organization which is the largest agriculturally focused volunteer network in the world as well as ECEAT / European Center for Eco-AgroTourism in Turkey (www.bugday.org). Close to 100 farms in various parts of Turkey and as parts of the Ta-Tu-Ta network endeavor to extend the practicalities of ecologic life and ecologic production they practice. Guests from Turkey and from various countries all over the world can volunteer to work on the farms included in the project or they can pay the contribution fee which has been determined for the farms and stay on as guests (http://www.ntvmsnbc.com).

The Buğday Association, which sustains its Ta-Tu-Ta projects on ecologic farms in various parts of Turkey acts as a guide to those who wish to be a guest on an ecologic farm. The Buğday Association plays a significant role in the sector by promoting agritourism and relevant works. It has been determined that the Buğday Association uses the following methods and tools to promote and market Ta-Tu-Ta farms and agritourism (Artuğer, Özkoç, \& Kendir, 2013):

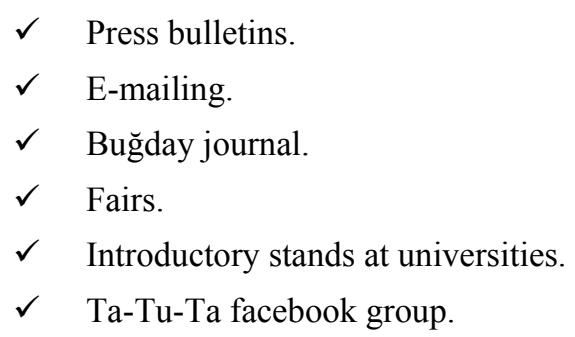

Buğday Association publishes press bulletins which introduce agritourism and the farms and sends relevant weekly promotion bulletins to individuals who are members of the e-bulletin. In addition, members of the Buğday Association receive a copy of the quarterly published Buğday Ecological Living Journal. In addition, introductory activities are carried out with stands which are erected from time to time at fairs and universities. The Buğday Association also cooperates with Gençtur which is a tourism agency catering to young people since 2007 to promote and market the Ta-Tu-Ta project. Local and foreign young people visiting the Gençtur office and its web site can get information about the project and help in getting accommodation at the farms (Artuğer et al., 2013).

The number of studies carried out to examine the motivation of agritourists to participate in agritourism are limited (Jolly \& Reynolds, 2005; Che, Veeck, \& Veeck, 2006; Srikatanyoo \& Campiranon, 2010). Jolly and Reynolds (2005) carried out a study in Sacramento and Yolo towns of California which revealed that the major motivation for agritourists to participate in agritourism was to purchase fresh home made products. Other motivations stated in sequence were relaxation, discovering nature, visiting relatives and friends as well as joining in farm activities. A study carried out by Che et al. (2006) in the state of Michigan revealed that a leading factor motivating agritourism was to buy fresh fruit and vegetables. A study carried out by Srikatanyoo and Campiranon (2010) in the city of Chiang Mai in Thailand portrayed that mental relaxation and enjoying nature were the main motivations of agritourists to participate in agritourism.

\section{Method}

The target population of this study which aimed to determine the motivations of agritourists to participate in agritourism consisted of Turkish agritourists who participated in agritourism in Turkey. In order to participate in agritourism in Turkey it is necessary to become a member of the Ta-Tu-Ta project. In order to find out the number of Turkish tourists participating in agritourism in Turkey, contact was made with the Ta-Tu-Ta project coordinator and we were informed that the number was 300 persons. Surveys which were prepared over a web site were sent through the project coordinator to the e-mail addresses of the 300 tourists who were the target population of this study. A waiting period of two months was allowed for the survey forms to be filled. At the end of this period 100 survey forms were filled by the tourists. The survey questions were sent once more to the e-mail addresses of the tourists in order to reach more people. Approximately one more month went by and at the end of this period 96 more survey forms were filled. In conclusion a total of 196 survey forms had been filled. This number is sufficient for the sample size table determined by Sekaran (2000, p.295). 
A survey technique was used to quantify the reasons for the agritourists participating in agritourism. The prepared survey consisted of two parts. The first part dealt with individual characteristics of the participants (gender, age, marital status, education level, profession, income level) and characteristics regarding their participation in agritourism (how many times they had participated in agritourism, who with, in what capacity they participated and how many nights they were accommodated at the farms) while the second part consisted of an agritourist motivations scale determined through 17 articles and 3 basic dimensions (Agricultural experiences, Quality of life, relationships, and adventure, Relaxations). The questions for this scale were obtained from a study carried out by Srikatanyoo and Campiranon (2010). The participation levels of the participants for each statement in this section was graded as "Strongly disagree=1", "Disagree=2", "Neutral=3", "Agree=4" and "Strongly agree $=5$ " in compliance with a five point likert scale.

First the frequency and distribution of the individual characteristics of the participants (gender, age, marital status, education level, profession, income level) and characteristics with their participation in agritourism (how many times they had participated in agritourism, who with, in what capacity they participated and how many nights they were accommodated at the farms) were determined. In addition, the arithmetical average and standard deviation values regarding the views of the participants in terms of their reasons for taking part in agritourism were portrayed. On the other hand, a factor analysis was applied in order to validate the structure of the agritourist motivations in the study and Cronbach's Alpha coefficients were calculated to test the reliability of the internal consistency. IBM SPSS 20.0 for Windows package program was used to analyze the obtained data.

\section{Findings}

Table 1. Findings related to the demographical characteristics of the participants and their participation in agritourism

\begin{tabular}{|c|c|c|c|}
\hline Variable & Group & Number(f) & Percentage (\%) \\
\hline \multirow[t]{2}{*}{ Gender } & Female & 118 & 60,2 \\
\hline & Male & 78 & 39,8 \\
\hline \multirow[t]{2}{*}{ Marital status } & Married & 76 & 38,8 \\
\hline & Single & 120 & 61,2 \\
\hline \multirow[t]{4}{*}{ Age } & $21-30$ & 78 & 39,8 \\
\hline & $31-40$ & 46 & 23,5 \\
\hline & $41-50$ & 34 & 17,3 \\
\hline & $51-60$ & 38 & 19,4 \\
\hline \multirow[t]{4}{*}{ Level of Education } & High school & 26 & 13,3 \\
\hline & Associate degree & 20 & 10,2 \\
\hline & Bachelor's degree & 124 & 63,3 \\
\hline & Postgraduate degree & 26 & 13,3 \\
\hline \multirow[t]{5}{*}{ Profession } & Civil Servant & 28 & 14,3 \\
\hline & Private sector employee & 65 & 33,2 \\
\hline & Retired & 29 & 14,8 \\
\hline & Student & 40 & 20,4 \\
\hline & Self employed & 34 & 17,3 \\
\hline \multirow[t]{6}{*}{ Level of income (monthly) } & $1000 \mathrm{TL}$ and less & 56 & 28,6 \\
\hline & $1001-2000 \mathrm{TL}$ & 55 & 28,1 \\
\hline & 2001-3000 TL & 36 & 18,4 \\
\hline & $3001-4000 \mathrm{TL}$ & 22 & 11,2 \\
\hline & $4001-5000 \mathrm{TL}$ & 12 & 6,1 \\
\hline & $5001 \mathrm{TL}$ and over & 15 & 7,7 \\
\hline \multirow[t]{2}{*}{ Status of previous participation in agritourism } & Yes & 196 & 100 \\
\hline & No & 0 & 0 \\
\hline \multirow[t]{3}{*}{ Number of times of participating in agritourism } & Once & 102 & 52,0 \\
\hline & Twice & 74 & 37,8 \\
\hline & Thrice & 20 & 10,2 \\
\hline \multirow[t]{4}{*}{ Whom did you participate in agritourism with } & Alone & 90 & 45,9 \\
\hline & My friends & 40 & 20,4 \\
\hline & Spouse/Partner & 42 & 21,4 \\
\hline & Family & 24 & 12,2 \\
\hline \multirow[t]{4}{*}{ How many nights of accommodation on average on agricultural farms } & 2 nights & 30 & 15,3 \\
\hline & 3 nights & 26 & 13,3 \\
\hline & 4 nights & 36 & 18,4 \\
\hline & 5 nights and more & 104 & 53,1 \\
\hline Total & & 196 & 100,0 \\
\hline
\end{tabular}


According to the findings in Table 1 most of the participants were women $(60,2 \%)$, single $(61,2 \%)$ in the age bracket of 21-40 with bachelor's and postgraduate degrees. Considering the professions of agritourists reveals that they consisted of civil servants $(14,3 \%)$, private sector employees $(33,2 \%)$, retired $(14,8 \%)$, students $(20,4 \%)$ and self-employed persons $(17,3 \%)$. It was evident that the income levels of the participants were concentrated in the $1000 \mathrm{TL}$ and less to $2000 \mathrm{TL}$ bracket while most had participated in agritourism once $(52,0 \%)$, alone $(45,9 \%)$, with friends $(20,4 \%)$, with spouse $(21,4 \%)$ and families $(12,2 \%)$ and most stayed for five nights and over on agritourism farms $(53,1 \%)$.

Table 2. Item, subscale, and total scale statistics for agritourist motivations scale

\begin{tabular}{|c|c|c|c|c|c|}
\hline Scales and items & Factor loadings & Eigenvalues & $\begin{array}{c}\% \text { of } \\
\text { variance }\end{array}$ & $\begin{array}{l}\text { Cronbach's } \\
\text { Alpha }\end{array}$ & $\begin{array}{c}\text { Mean } \\
(\mathbf{1 - 5}) \\
( \pm \text { SD })\end{array}$ \\
\hline Factor 1: Agricultural experiences & & $\begin{array}{c}5,65 \\
8\end{array}$ & 27,074 & 0,840 & $3,96 \pm 0,84$ \\
\hline To improve agricultural skills & 0,852 & & & & $3,79 \pm 1,09$ \\
\hline To attend agricultural event or festival & 0,734 & & & & $3,61 \pm 1,19$ \\
\hline To experience agricultural life and activities & 0,895 & & & & $4,14 \pm 1,01$ \\
\hline To be in an agricultural environment & 0,709 & & & & $4,29 \pm 0,74$ \\
\hline $\begin{array}{l}\text { Factor 2: Quality of life, relationships and } \\
\text { adventure }\end{array}$ & & $\begin{array}{c}2,54 \\
8\end{array}$ & 21,820 & 0,759 & $4,08 \pm 0,71$ \\
\hline To build strength in relationships & 0,786 & & & & $3,93 \pm 1,08$ \\
\hline To improve health and well-being & 0,583 & & & & $4,43 \pm 0,78$ \\
\hline To enjoy life & 0,607 & & & & $4,55 \pm 0,67$ \\
\hline To have an adventure & 0,571 & & & & $3,62 \pm 1,22$ \\
\hline $\begin{array}{l}\text { To make friends or meet people with } \\
\text { similar interests }\end{array}$ & 0,746 & & & & $3,87 \pm 1,11$ \\
\hline Factor 3: Relaxation & & $\begin{array}{c}1,18 \\
9\end{array}$ & 18,212 & 0,901 & $4,41 \pm 0,69$ \\
\hline To escape from day-to-day stress & 0,877 & & & & $4,21 \pm 1,01$ \\
\hline To get away from city life & 0,858 & & & & $4,39 \pm 0,84$ \\
\hline To relax physically & 0,906 & & & & $4,28 \pm 0,90$ \\
\hline To relax mentally & 0,824 & & & & $4,49 \pm 0,72$ \\
\hline To enjoy scenery & 0,631 & & & & $4,70 \pm 0,52$ \\
\hline Total Scale Reliability and Variance & & & $\begin{array}{c}67 \\
106\end{array}$ & 0,865 & \\
\hline \multicolumn{2}{|c|}{ Kaiser-Meyer-Olkin Measure of Sampling Adequacy: KMO=0,832; } & \multicolumn{4}{|c|}{ Bartlett's Test of Sphericity: $\chi^{2}=1699,252 ; P=0,000$} \\
\hline
\end{tabular}

Table 2 consists of the applied factor analysis and reliability analysis (Cronbach's Alpha) results applied as a scale regarding the motivations of agritourists to participate in agritourism and arithmetical average and standard deviation values for the views regarding the participation of the participants in agritourism. At the completion of the factor analysis three factors which explained a scale over eigenvalue 1 and a total variance of $67,106 \%$ were determined. According to Hair, Black, Babin, Anderson and Tatham (2005) factor loads less than 0.40 are evaluated as low factor load. Since the factor loads of "purchase farm products", "spend time with my family", "discover new places and things' are below 0.40 they have been omitted from the factor analysis. For this reason the agritourist motivations scale in this study consists of 3 dimensions and 14 statements. On the other hand, the Bartlett's test result in the factor analysis for the scale revealed that factor analysis can be applied $(p<0,01)$ and that the Kaiser-Meyer-Olkin value revealed that the sampling volume was at a sufficient level. In addition, it was determined that Cronbach's Alpha value calculated for the scale was 0,865. These values show that the internal consistency level of the scale is adequate.

A perusal of the arithmetical averages in Table 2 reveals that the arithmetical average value of the relaxation dimension relevant to the reasons for participation in agritourism is $(\overline{\mathrm{X}}=4,41)$, the relevant arithmetical average value for the life, relationship quality and adventure dimension is $(\bar{X}=4,08)$ while the value for the arithmetical average for the agricultural experiences dimension is $(\overline{\mathrm{X}}=3,96)$. According to these findings Turkish agritourists 
participate in agritourism in order to escape the stress of daily life, get away from the city, relax mentally and physically and enjoy nature more than compared to other reasons.

Table 3. Ranking of the mean agritourist motivations

\begin{tabular}{|c|c|c|}
\hline \multicolumn{3}{|c|}{ Descriptive statistics } \\
\hline & $\begin{array}{c}\text { Mean } \\
\text { statistic* }\end{array}$ & $\begin{array}{c}\text { Std. deviation } \\
\text { statistic }\end{array}$ \\
\hline To enjoy scenery & 4,70 & 0,52 \\
\hline To enjoy life & 4,55 & 0,67 \\
\hline To relax mentally & 4,49 & 0,72 \\
\hline To improve health and well-being & 4,43 & 0,78 \\
\hline To get away from city life & 4,39 & 0,84 \\
\hline To be in an agricultural environment & 4,29 & 0,74 \\
\hline To relax physically & 4,28 & 0,90 \\
\hline To escape from day-to-day stress & 4,21 & 1,01 \\
\hline To experience agricultural life and activities & 4,14 & 1,01 \\
\hline To strengthen relationships & 3,93 & 1,08 \\
\hline To make friends or meet people with similar interests & 3,87 & 1,11 \\
\hline To improve agricultural skills & 3,79 & 1,09 \\
\hline To have an adventure & 3,62 & 1,22 \\
\hline To attend agricultural events or festivals & 3,61 & 1,19 \\
\hline
\end{tabular}

Note: $\mathrm{N}=196 ; * 5$-point likert scale.

According to Table 3 it is evident that "enjoying the scenery" $(\overline{\mathrm{X}}=4,70)$ is the main motivation of the agritourists. In comparison, the lowest average for agritourist participation appeared to be "to attend agricultural events or festivals' $(\bar{X}=3.61)$ which was the last on the list.

\section{Discussion and Conclusions}

Agritourism appears to be significant type of alternative tourism to mass tourism which continues to rule in the world. Nature and the environment which are significant particularly for the sustainability of tourism in terms of mass tourism are being destroyed on a major scale. Although even developed countries carry out necessary works and take precautions to conserve nature and the environment, due to the nature of mass tourism damage is unavoidable. In addition, during the past years people who want to distance themselves from the hectic and stressful urban life and take refuge in the arms of nature have taken an intense interest in agritourism all over the world.

This study which endeavored to determine the motivations of agritourists to participate in agritourism revealed that agritourists choose agritourism for reasons such as to enjoy the scenery, enjoy life and relax mentally. In other words, agritourists participate in agritourism in order to relax mentally or physically and be in touch with nature. Srikatanyoo and Campiranon (2010) who carried out a study in Chiang Mai, a city in Thailand, achieved similar results. The research carried out by the authors showed that the main motivations of agritourists were mental relaxation and to enjoy nature. Jolly and Reynolds (2005) carried out a study in California's Sacramento and Yolo cities to determine the motivations of agritourists to participate in agritourism. The study results showed that the main motivation of agritourists was to buy home made fresh products. The other reasons are sequenced as resting, discovering nature, visiting friends and family and participating in farm activities. In a study carried out by Che et al. (2006) in Michigan state it was discovered that the main motivation of agritourists to participate in agritourism was to buy fresh fruit and vegetables.

This study revealed that agritourists participated in agritourism to relax rather than to participate in agricultural experiences. For this reason at this point it is possible to make some suggestions to farm owners/managers who are active in agritourism in Turkey. Instead of prioritizing the organization of agricultural activities such as agricultural events or festivals, farm owners would do better to ensure an environment where tourists can relax mentally and physically, rest and be in a natural habitat.

A study of international literature reveals that the number of studies dealing with agritourists and particularly studies related to the motivations of agritourists to participate in agritourism are very few. It is believed that this 
study will make a significant contribution in this area. Researchers can contribute to the gap in this area by carrying out studies to reveal the motivations of agritourists to participate in agritourism in different countries in the world and compare the results with those of the few existing studies.

\section{Acknowledgement}

We wish to thank the esteemed Ahmet Berkay Atik, the project coordinator of Ta-Tu-Ta (Agriculture-Tourism-Exchange) in Turkey who shared his knowledge and views generously and gave his full support in the application of the surveys. In addition, we also owe the officers of Buğday Association a thank you for their interest and information sharing.

\section{References}

Artuğer, S., Özkoç, A. G., \& Kendir, H. (2013). Ta-Tu-Ta (tarım-turizm-takas) çiftliklerinin pazarlanması ve tanıtılması için öneriler. Uluslararası Sosyal ve Ekonomik Bilimler Dergisi, 3, 1-5.

Barbieri, C. (2010). An importance-performance analysis of the motivations behind agritourism and other farm enterprise developments in Canada . Journal of Rural and Community Development, 5, 1-20.

Barbieri, C., \& Mshenga, M. P. (2008). The role of the firm and owner characteristics on the performance of agritourism farms. Sociologia Ruralis, 48, 166-183. http://dx.doi.org/10.1111/j.1467-9523.2008.00450.x

Busby, G., \& Rendle, S. (2000). The transition from tourism on farms to farm tourism. Tourism Management, $21,635-642$.

Che, D., Veeck, A., \& Veeck, G. (2006). Demographic characteristics and motivations of Michigan agritourists. Proceedings of the 2006 Northeastern Recreation Research Symposium, General Technical Report NRS-P-14 (pp. 98-103).

Hair, J. F., Black, B., Babin, B., Anderson, R. E., \& Tatham, R. L. (2005). Multivariate data analysis (6th ed.). Upper Saddle River, NJ: Prentice Hall.

Jolly, A. D., \& Reynolds, A. K. (2005). Consumer demand for agricultural and on-farm nature tourism. uc small farm center research brief. Retrieved from http://sfp.ucdavis.edu/files/143466.pdf

McGehee, G. N., \& Kim, K. (2004). Motivation for agri-tourism entrepreneurship. Journal of Travel Research, 43, 161-170. http://dx.doi.org/10.1177/0047287504268245

McGehee, G. N., Kim, K., \& Jennigs, R. G. (2007). Gender and motivation for agri-tourism entrepreneurship. Tourism Management, 28, 280-289. http://dx.doi.org/10.1016/j.tourman.2005.12.022

Mitchell, J. T. (2006). Conflicting threat perceptions at a rural agricultural fair. Tourism Management, 27, 1298-1307. http://dx.doi.org/10.1016/j.tourman.2005.06.004

Nickerson, N. P., Black, R. J., \& McCool, S. F. (2001). Agritourism: Motivations behind farm/ranch business diversification. Journal of Travel Research, 40, 19-26. http://dx.doi.org/10.1177/004728750104000104

Przezborska, L. (2003). Relationships between rural tourism and agrarian restructuring in a transitional economy: the case of Poland. Directions in Rural Tourism, Aldershot: Ashgate.

Sekaran, U. (2000). Resarch Methods For Business: A Skill-Building Approach (3rd ed.). New York: John Wiley \& Sons.

Srikatanyoo, N., \& Campiranon, K. (2010). Agritourist needs and motivations: The Chiang Mai case. Journal of Travel \& Tourism Marketing, 27, 166-178. http://dx.doi.org/10.1080/10548400903579795

Tatilinizi Planlamadan Önce. (2012, June 19). Ntvmsnbc. Retrieved from http://www.ntvmsnbc.com/id/25359520/

Ta-Tu-Ta Projesi. (2013, June 20). Buğday Derneği. Retrieved from http://www.bugday.org/portal/projeler.php?pid=41

Weaver, D. B., \& Fennell, D. A. (1997). The vacation farm sector in saskatchewan: A profile of operations. Tourism Management, 18, 357-365. http://dx.doi.org/10.1016/S0261-5177(97)00039-3

Yang, L. (2012). Impacts and challenges in agritourism development in Yunnan, China. Tourism Planning \& Development, 9, 369-381. http://dx.doi.org/10.1080/21568316.2012.726257 


\section{Copyrights}

Copyright for this article is retained by the author(s), with first publication rights granted to the journal.

This is an open-access article distributed under the terms and conditions of the Creative Commons Attribution license (http://creativecommons.org/licenses/by/3.0/). 